\title{
The State of the Australian Middle Class
}

\author{
Clive Hamilton, Christian Downie and Yi-Hua Lu
}

\begin{abstract}
There is a widespread view that the middle class in Australia is doing it tough, that they are finding it increasingly difficult to maintain a decent standard of living and are suffering from mortgage stress. Indeed, some media reports have announced the end of the middle class dream.

This paper tests a number of these popular views against the statistical data. It asks whether the typical Australian family can be said to be struggling? Are mortgages creating severe problems for middle-class families? Is the middle class shrinking? Are families coping financially only because wives are going out to work?
\end{abstract}

Keywords: middle class; pressure; Australia; middle class dream; struggle

Acknowledgements:

The authors would like to thank Professor Frank Stilwell for refereeing this paper. The authors are also grateful to staff from the ABS and HILDA for their assistance with the statistics used in this paper. Notwithstanding their input, any errors remain the responsibility of the authors.

The data used for this research come from the Household Income and Labour Dynamics in Australia (HILDA) survey and the Australian Bureau of Statistics (ABS). HILDA is funded by the Department of Family, Community Services and Indigenous Affairs (FaCSIA) and conducted by the Melbourne Institute for Economic and Social Research at the University of Melbourne. The research findings and the views expressed are those of The Australia Institute and should not be attributed to FaCSIA, the Melbourne Institute or the ABS.

\section{Introduction.}

There is a widespread view that the middle class in Australia is doing it tough. Beset by mortgage stress and rising prices they are being forced to tighten their belts. Media stories, commentaries and political rhetoric constantly reinforce this narrative. One newspaper has announced the 'death of the great middle-class dream'.

A number of academic studies have served to entrench the view of the struggling middle class suggesting that it is being 'hollowed out' and under sustained pressure from economic reform.

The Government seems caught. On the one hand it wants to emphasise the way in which sustained economic growth has improved real incomes, yet knows that saying that Australians have never had it so good, while economically true, does not gel with the widespread sense of middle-class grievance.

In this paper we test a number of popular views about the state of the Australian middle class against the statistical data. Using data from the ABS and HILDA, we pose and answer the following questions:

1. Can the typical Australian family be said to be struggling?

2. Are mortgages creating severe problems for middle-class families? 
3. Is the middle class shrinking?

4. Are families coping financially only because wives are going out to work?

\section{Is the typical Australian family struggling?}

When we think of the typical Australian family we do not think of young singles, childless couples, empty nesters or retirees. A truer picture of the economic well-being of the typical Australian family is given by looking at the incomes of those households comprised of a couple with at least one dependent child and headed by someone of prime working age. These households account for 41 per cent of the population.

In 2005 the median disposable income of all households was $\$ 48,193$. In contrast, the median disposable income of the typical Australian family as we have defined it was $\$ 69,073,43$ per cent higher. The average income for these households was $\$ 76,778,37$ per cent higher than the average for all households. The standard of living afforded by a disposable income close to $\$ 70,000$ is comfortable by any measure and conflicts with the widespread view of struggling families.

Do the median and mean figures conceal a wide disparity in income levels among typical families? In fact the spread of incomes is significantly narrower for typical families than for all households. There are very few typical families with low incomes; only 18 per cent have disposable incomes below $\$ 45,000$. The picture is very different for single parent families where low incomes are much more prevalent and the narrative of struggling families has much greater validity.

\section{Are mortgages killing the middle class?}

There is a widespread view that Australians are suffering from 'mortgage stress' and that the pain has spread to middle-class suburbs across the nation. Media reports give the impression that the bulk of the population is finding it difficult to make ends meet as mortgage repayments rise.

In fact, very few middle-class households suffer from any form of mortgage stress. Defining 'middle class' as those households with disposable incomes between the $30^{\text {th }}$ and the $80^{\text {th }}$ percentiles, nearly two-thirds (63 per cent) of middle-class households do not have mortgages at all. Of those who do, 41 per cent have mortgages under $\$ 100,000$ and nearly 80 per cent under $\$ 200,000$. Only eight per cent of middle-class households have mortgages over $\$ 200,000$.

\section{Is the middle class shrinking?}

The popular narrative of the struggling middle class sometimes suggests that, because of an inability to cope with financial pressures, the middle class is shrinking, even 'disappearing'. Here we first define the middle class as those with disposable incomes higher than the bottom 30 per cent and lower than the richest 20 per cent. Did the middle class shrink over the 11year period 1994-95 to 2005-06 and, if so, did those who left its ranks get pushed up or dragged down?

To answer this question, we used the following technique. For the base year 1994-95, we first found, as multiples of the median, the lower and upper income boundaries of the 'middle' 50 per cent of households (i.e. those with disposable incomes between the $30^{\text {th }}$ and the $80^{\text {th }}$ percentiles). Then we took the median level of disposable income for 2005-06 and applied the 
1994-95 multiples of the median to the 2005-06 median to find the new cut-off points for the middle class. Finally, we calculate the proportion of households that fell within these cut-off points in 2005-06. If it is less than 50 per cent of all households then the middle class has shrunk, if more than 50 per cent then it has grown.

The results show that the middle class has not shrunk over the 11 years to 2005-06 but has in fact grown slightly, from 50 per cent of households to 51.1 per cent of households. The difference is small but it disproves the claim that the middle class is shrinking, at least when measured in this way. The growth in the middle class has been due mostly to a small migration of households from the high-income category.

Obviously, the incomes of all groups grew over the period in question. But did they grow by the same extent? The analysis shows that, although the average real income of the middle class rose 27 per cent over the 11 years to 2005-06, low-income households saw their incomes rise by 33 per cent and those of high-income households grew by 31 per cent.

\section{Are 'working wives' saving the day?}

It has been suggested that the only reason household incomes have increased is because women in couple households have been working longer hours. To test this we compared the increase in mean disposable incomes of couple households over the period 1994-95 to 200506 with the increase that would have occurred if the females in the couple households ('wives') had not increased their hours of work from the levels in the earlier year.

Average disposable incomes of couple households increased from $\$ 51,201$ to $\$ 68,668$ over the 11 years to $2005-06$, a rise of 34 per cent. The analysis shows that increased working hours by females in couple households accounts for only 18 per cent of the increase in household income over the 11 years to 2005-06, although the effect is stronger for households in the second and third quintiles.

\section{Perception versus reality}

The data show that few typical Australian families are struggling financially; in fact, most are doing very well. Contrary to the headlines, fewer than one in ten middle-class households are suffering from mortgage stress; most do not have mortgages. How can the difference between the perception of middle-class distress and real financial health be explained? Three factors may be at work.

Firstly, the constant reinforcement of the message of middle-class distress may persuade Australians that this describes their own situation irrespective of their real financial position.

Second, there is considerable evidence that middle-class Australians focus not on what they have but on the gap between what they have and what they want, creating a sense of material deprivation in a time of plenty. This not only prevents people from appreciating their good fortune but induces government to provide welfare to households that are not in need.

Third, middle-class Australians may be displacing anxieties about moral decline, pressure to succeed and fears about world affairs onto financial concerns. In other words, when middleclass Australians believe they are struggling, it may be that they are struggling with things other than their finances. 


\section{Images of the Australian middle class}

Middle-class Australians are doing it tough. They are finding it increasingly difficult to maintain a decent standard of living. Mortgage stress is biting hard with recent rises in interest rates, and belts are being tightened, a situation not helped by rising prices of petrol and groceries.

At least, this is the impression of the state of the middle class according to popular discussion, media reports and political oratory. Both sides of politics deploy the rhetoric of 'struggling families' and 'battlers', presumably because they want to communicate that they can feel the pain of 'ordinary families' and take measures to 'ease the squeeze'.

A number of academic studies in recent years have reinforced the view of the struggling middle class. Using measures of wage rates, Bob Gregory (1993) showed that during the 1970s and 1980s the middle class was being 'hollowed out'. Michael Pusey (2003) argued that middle Australia sees itself suffering as a result of economic reform - increasingly pressured, time squeezed, anxious about bills and worried about moral decline.

Pusey reports a widespread view among 'middle Australia' that people are having to make 'tremendous effort and sacrifice' in order to get along, their 'deepening insecurity' and the 'pain' that they experience as a result, for example, of the decision to send their children to private schools (Pusey 2003, p. 78-9). Most perceive a widening gap between 'the haves and the have-nots' and many see themselves at the wrong end of the divide.

Based on work carried out by the National Centre for Social and Economic Modelling (NATSEM), The Australian newspaper in 2000 announced the 'Death of the nation's great middle-class dream' (The Australian 2000).

In short, middle-class Australians appear to have a sense of grievance, one constantly reinforced by the media and politicians. But how much pain is the middle class really experiencing? Hamilton (2003) has argued that a distinction should be drawn between real and imagined hardship, and that many middle-class and even wealthy Australians feel a sense of material deprivation because they focus less on what they have than on the gap between what they have and what they want. This 'deprivation syndrome' explains the sense of grievance that political leaders appeal to and reinforce.

The public debate that has generated, or at least perpetuated, the sense of middle-class deprivation is fuelled by various studies and statistical publications that produce numbers that seem to support the view. But those who work with numbers know that their meaning is highly dependent on context and interpretation. On the other hand, well-chosen and clearly interpreted numbers can transform our understanding of social situations.

In this paper we test a number of popular views about the state of the Australian middle class against the statistical data. The data sources and methods used in this analysis are set out in detail in the appendix. Only the most important concepts, steps and data issues are described in each section below as they apply to that section. We pose and answer the following questions:

1. Can the typical Australian family be said to be struggling? 
2. Are mortgages creating severe problems for middle-class families?

3. Is the middle class shrinking?

4. Are families coping financially only because wives are going out to work?

By answering these questions we will be in a better position to assess the reality or otherwise of popular views about the middle class and whether we should be concerned about its situation. But first, we comment briefly on the issues of inequality and poverty, which will help define the focus of this paper more clearly.

\section{Poverty and inequality}

In scrutinising the basis of middle-class complaint in this paper we are not questioning the extent of genuine hardship among those at the bottom of the income distribution. Over the last decade income inequality in Australia has increased a little. Between 1994-95 and 2005-06 the Gini-coefficient rose slightly from 0.302 to 0.307 (ABS 2007). ${ }^{1}$ Judging by the widespread use of the phrase 'the rich are getting richer and the poor are getting poorer', the public seems to think that inequality has worsened by much more. The widening gap between rich and poor, however slight, could be due to one of four situations:

1. the poor getting richer but the rich getting richer by a greater amount;

2. the poor staying where they are while the rich get richer;

3. the poor getting poorer while the rich stay where they are; or

4. the poor getting poorer while the rich get richer.

In welfare terms the difference matters a great deal. Most people would agree that the situation is morally worse as we go from 1 to 2 to 3 to 4 . In fact, most Australians say they would prefer some redistribution of income from the rich to the poor, i.e. a narrowing of the gap between rich and poor (Pusey 2003).

Since the mid-1990s in Australia situation 1 or 2 is closest to the mark. This period has largely been one of rising real incomes and prosperity for most Australians. According to the latest analysis from the National Centre for Social and Economic Modelling (NATSEM), 'incomes at the bottom of the income spectrum rose somewhat more slowly than for the middle between the mid 1990s and 2002-03, resulting in higher poverty rates and rising income inequality'. Rising poverty rates are due to the definition of poverty in relative terms as a deviation from a rising median. ${ }^{2}$ However, it would appear that both these trends may have reversed between 2002-03 and 2003-04 (Harding et al. 2007, p. 16).

In this paper we consider the situation of the middle class which we mostly define to exclude those households that fall in the bottom 30 per cent of the distribution of gross or disposable income. The bottom 30 per cent includes all those living in poverty, however poverty is

\footnotetext{
${ }^{1} \mathrm{~A}$ Gini-coefficient of 0 is equal to perfect equality and a value of 1 is equal to perfect inequality. An increase in the coefficient thus represents a worsening of income distribution. This increase could be affected by changes in the ABS's methodology (ABS 2007).

${ }^{2}$ It is sometimes measured in relative terms as a deviation from the mean (Saunders 2005).

Permission to reprint this article in this journal was given by The Australia Institute and the Authors. This work originally appeared as Discussion Paper 98, October, 2007 on the Australia Institute Website at www.tai. org.au 
defined. At the very most 23 per cent of Australians are living in poverty, but estimates vary widely with some as low as five per cent (SCARC 2004). Despite the so-called 'poverty wars' over where the poverty line should be set, it is generally accepted that somewhere between 10 and 15 per cent of Australians experience poverty at any one time (Saunders 2005). ${ }^{3}$

\section{Is the typical Australian family struggling?}

The most widely quoted figure used to indicate the financial position of Australian families is the ABS's median household disposable income. In 2005-06 the median, or middle, level of disposable income for Australian households was \$46,613 (\$894/week) (ABS 2007). Using HILDA data the median disposable income for all households in 2005 was $\$ 48,193 .{ }^{4}$ This figure includes all types of households, including those headed by workers just starting out on their careers and those at the end of them or retired. Early in adulthood and after retirement incomes are usually much lower than during prime working age. If we count only households headed by an adult aged between 25 and 54, the range usually used to define prime working age, the typical level of disposable income increases from $\$ 48,193$ to $\$ 58,282,21$ per cent higher. Median and mean household incomes for various household types are shown in Table 1. The medians are graphed in Figure 1.

When we think of the typical Australian family we do not think of young singles, childless couples, empty nesters or retirees. A truer picture of the economic well-being of the typical Australian family is given by looking at the incomes of those households comprised of a couple with at least one dependent child and headed by someone of prime working age. ${ }^{5}$ As Figure 2 shows, these typical families make up 25 per cent of all households, while all prime age households comprise 58 percent of the total. Although only a quarter of households, prime age couples with children make up 41 per cent of the population, and all prime age households account for 68 per cent of the population.

It is apparent from Table 1 that in 2005 the median disposable income of the typical Australian family was $\$ 69,073,43$ per cent higher than the median income for all households. The average income for these households was $\$ 76,778,37$ per cent higher than the average for all households. The standard of living afforded by a disposable income close to $\$ 70,000$ is comfortable by any measure and conflicts with the widespread view of struggling families.

But perhaps the median and mean figures conceal a wide disparity in income levels among typical families. In fact the opposite is the case. Figure 3 shows the distribution of disposable incomes for all households and households comprised of prime working age couples with children. It is apparent that the spread of incomes is significantly narrower for typical families than for all households. Using the inter-quartile range as a measure of spread, the middle 50 per cent of prime age couple households with children have disposable incomes ranging from $\$ 51,321$ to $\$ 91,389$ (so a quarter receive less than the lower amount and a quarter receive more than the higher amount). The equivalent range for all households is $\$ 24,541$ to $\$ 72,083$. This gives an inter-quartile range for typical families of a little over $\$ 40,000$ compared to around $\$ 47,500$ for all households. In other words, there are very few typical families with

\footnotetext{
${ }^{3}$ The difficulty in defining poverty suggests that new approaches are needed. One example is the preliminary work being undertaken by Headey (2007) and researchers at HILDA to create household financial accounts, which will consider wealth and consumption in addition to income. Another example is Vinson's (2007) work that identifies areas of concentrated disadvantage in Australia.

${ }^{4}$ The discrepancies between ABS and HILDA data are explained in the methods section in the appendix.

${ }^{5}$ The definition of a dependent child is explained in the appendix.

Permission to reprint this article in this journal was given by The Australia Institute and the Authors. This work originally appeared as Discussion Paper 98, October, 2007 on the Australia Institute Website at www.tai. org.au 
low incomes; only 18 per cent of typical families have disposable incomes below $\$ 45,000$. While comfortable for a single person, an income of $\$ 45,000$ is modest for a family with two adults and one or more children. It should also be remembered that this analysis applies only to couple families; the picture is very different for single parent families where low incomes are much more prevalent. In the case of these households the narrative of struggling families has much greater validity.

\section{Table 1 Median and mean disposable incomes by household type, 2005}

\begin{tabular}{lcccc} 
& \multicolumn{2}{c}{ Median } & \multicolumn{2}{c}{ Mean } \\
\cline { 2 - 5 } & Level & $\begin{array}{c}\text { Increase } \\
\text { on all } \\
\text { households }\end{array}$ & Level & $\begin{array}{c}\text { Increase } \\
\text { on all } \\
\text { households }\end{array}$ \\
All households & $\$ 48,193$ & - & $\$ 55,969$ & - \\
Prime age & $\$ 58,282$ & $21 \%$ & $\$ 64,432$ & $15 \%$ \\
Prime age couples & $\$ 70,639$ & $47 \%$ & $\$ 77,043$ & $38 \%$ \\
Prime age couples with children & $\$ 69,073$ & $43 \%$ & $\$ 76,778$ & $37 \%$ \\
\hline
\end{tabular}

Source: HILDA, Wave 5

Figure 1 Median disposable income by household type, 2005

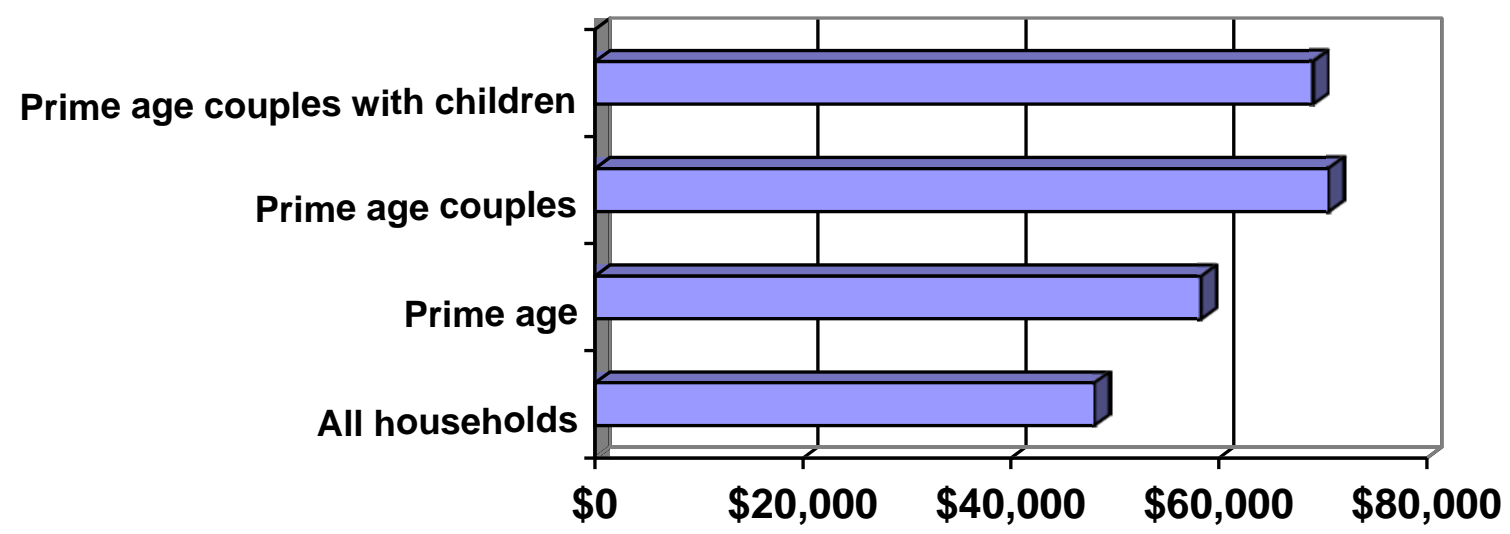

Source: HILDA, Wave 5 
Figure 2 Shares of household types, 2005

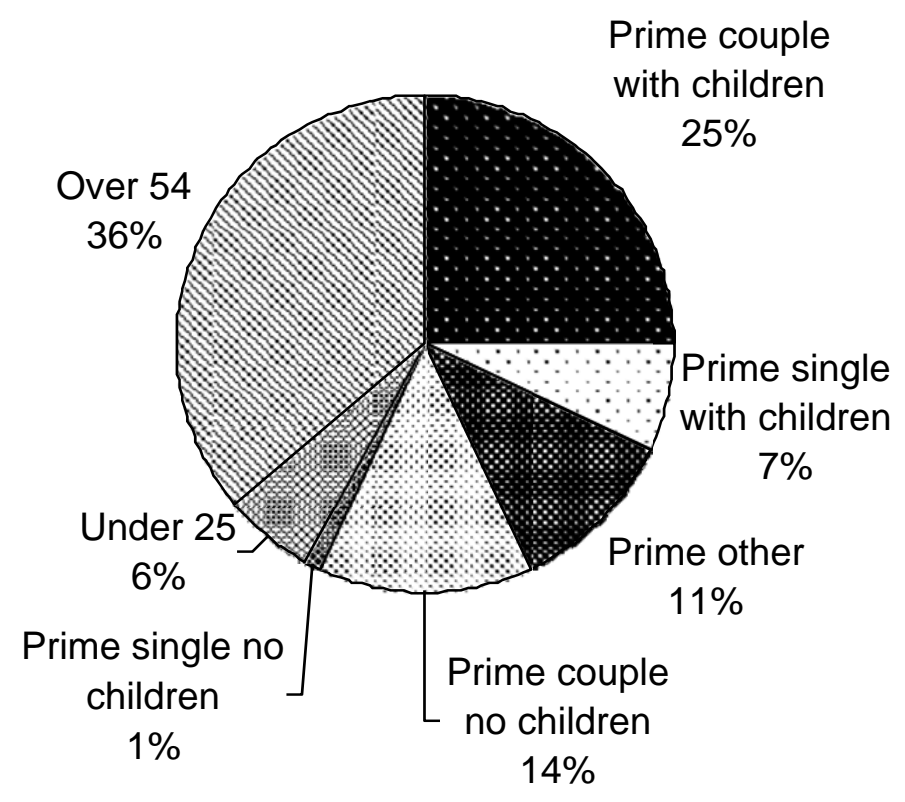

HILDA, Wave 5

Source:

Figure 3 Annual disposable income, all households and prime age couples with children, 2005 (per cent)

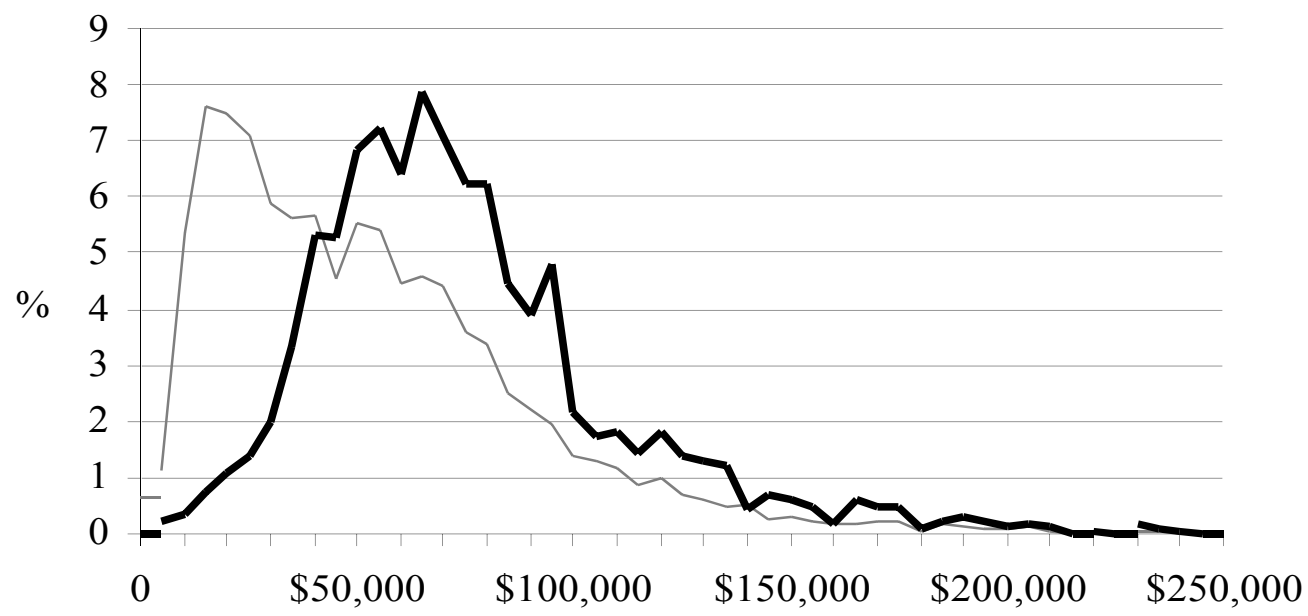

Source: HILDA, Wave 5

Permission to reprint this article in this journal was given by The Australia Institute and the Authors. This work originally appeared as Discussion Paper 98, October, 2007 on the Australia Institute Website at www.tai. org. au

(C) The Australia Institute 2008

This work is copyright. It may be reproduced and communicated to the public for the purposes of fair dealing as provided by the Copyright Act 1968. The author maintains their moral rights in this work. Requests and inquiries should be directed to The Australia Institute. 


\section{Are mortgages killing the middle class?}

There is a widespread view that Australians are suffering from 'mortgage stress' and that the most pain is being felt in middle-class suburbs across the nation, even extending into the wealthiest suburbs. It is a hot political issue, one fanned by media reports.

Launching the Australian Mortgage Industry 'Stress-O-Meter' in 2007, Fujitsu Consulting estimated that 70,000 households are now experiencing mortgage stress across Australia, a 52 per cent rise in the last 12 months. The consulting group stated that "while the traditional "battlers" continue to be hit hard, the extent of mortgage stress, and potential problems, have now reached mainstream Australia' (Fujitsu 2007). Media reports interpreted the survey results as confirmation that the bulk of the population is finding it difficult to make ends meet. The Herald Sun in Melbourne led with the headline 'Mortgage stress on the rise' and carried claims that mortgage stress is 'moving further and further into middle suburbia' (Ife 2007).

A similar message was delivered by a series of prominent stories in the Sydney newspapers. The Daily Telegraph ran a front page with the headline 'Living on the edge' and the Sydney Morning Herald described the story of a single mother 'Gambling on good health to make ends meet' and pay-off her mortgage. The papers dwelt on the 'suffering' and the growing number of households experiencing 'mortgage stress' (Vallejo 2007; Tibbits 2007). Some of the articles discussed the position of people on low incomes, who experience genuine hardship, as if the circumstances of these people are equivalent to those of middle-class mortgagors. The tenor of the articles was that large numbers of Sydney residents find themselves under financial pressure because of the size of their mortgage repayments compared to their incomes.

The popular impression that most Australians are doing it tough and are trapped in a difficult situation that is not of their making is reinforced by political leaders. In July, the Shadow Treasurer stated that 'half a million households are in stress. ... They're in stress. They're finding it hard to make ends meet' (Swan 2007). The Treasurer and the Prime Minister echo these comments but they have the difficult job of simultaneously sympathising with 'struggling' Australians and explaining to the same people that the economy has been growing strongly and they have never had it so good. In July, when asked whether he thought people 'are doing it tough', the Treasurer replied, 'I think people are always doing it tough'. Yet in the next sentence he said:

People always have worries. But if you are worrying about getting a job, your worry should be a lot less today than 10 years ago. If you are worried about interest rates they are a lot lower than they were 10 years ago. If you are worried about incomes, they are higher than they were 10 years ago (Costello 2007).

The truth is that very few middle-class households can be suffering mortgage stress because very few middle-class households have large mortgages. Using the HILDA Survey and defining 'middle class' as those households with disposable incomes between the $30^{\text {th }}$ and the $80^{\text {th }}$ percentiles, Figure 4 shows the size of mortgages. Nearly two-thirds ( 63 per cent) of middle-class households do not have mortgages at all. Of those who do, 41 per cent have mortgages under $\$ 100,000$ and nearly 80 per cent under $\$ 200,000 .^{6}$ Of those middle-class households that have mortgages the median amount owing (including second mortgages on

\footnotetext{
${ }^{6}$ The definition of a mortgage is explained in the appendix.

Permission to reprint this article in this journal was given by The Australia Institute and the Authors. This work originally appeared as Discussion Paper 98, October, 2007 on the Australia Institute Website at www.tai. org.au 
the same residential property) is $\$ 125,000$. Only eight per cent of middle-class households have mortgages over $\$ 200,000$.

Figure 4 Share of mortgages held by middle-class households, by size of mortgage, 2005 (per cent)

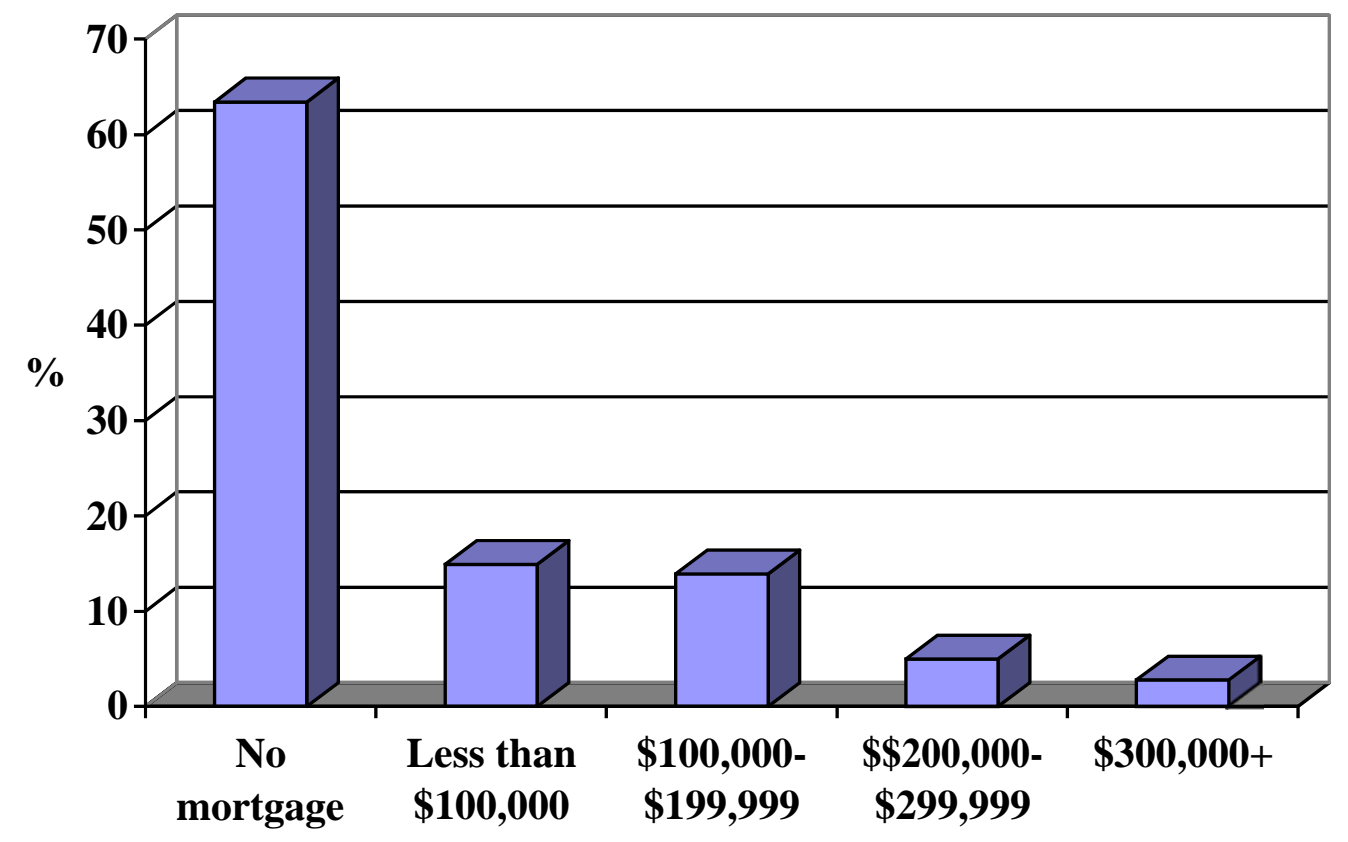

urce: HILDA, Wave 5

\section{Is the middle class shrinking?}

The popular narrative of the struggling middle class sometimes suggests that, because of an inability to cope with financial pressures, the middle class is shrinking. Many families are said to be finding it increasingly difficult to make ends meet and are dragged into a lower category. In a widely-quoted study in 1993, Bob Gregory drew on an analysis of occupations and wage rates to detect a 'disappearing middle' in Australia during the 1970s and 1980s (Gregory 1993). Since his study newspaper reports have built on this idea, sometimes construing rising income inequality as evidence of the disappearing middle. Reports have chronicled the 'hollowing out' and 'thinning' of the middle class (Megalogenis 2005; Magill 2004; Rintoul 2000).

The analysis by Gregory helped to transform the way the middle class is perceived in Australia. Looking at male full-time employees, Gregory found that since the mid-1970s the ratio of male full-time employees to the population had fallen by 25 per cent. Importantly, his study found that one in three jobs lost had been located among middle-earning jobs. Gregory also showed that employment growth in the high-income brackets had failed to keep pace with population increases, up by 23 per cent between 1976 and 1990. However, employment in the low-income brackets had grown by 43 per cent. In short, Gregory's analysis indicated that as the jobs in the middle-income groups disappeared most of the new ones were being created in low-income brackets (Gregory 1993). 
In order to test whether the middle class is disappearing we first need to define what we mean by the middle class. This is a notoriously tricky subject as traditionally class has been analysed in terms of occupation, social status and culture as well as income. Social and cultural barriers to class mobility have become much more porous in recent decades and a large majority of Australians would define themselves as middle class. Surveys in which respondents are asked to define their social position have shown fewer and fewer people willing to identify themselves as working class. There are good reasons for confusion. Should a plumber earning $\$ 90,000$ a year properly described as 'working class' while a university graduate working as a public servant on $\$ 45,000$ should be called 'middle class'? And do we have an 'upper class', or are the very rich just a wealthier category of the middle class?

There does not seem to be any survey evidence on identification with class terms, although Australians have been asked about how they identify their income levels. Indeed, 93 per cent of Australians believe they are in the middle-income bracket (that is, the middle 60 per cent) and only 6.4 per cent see themselves in the bottom 20 per cent and 0.7 per cent in the top 20 per cent (Saunders et al. 2000, p. 19). If almost everyone thinks of themselves as middle income, and this morphs into the vague term 'middle class', popular talk of the pain experienced by the middle class probably means most Australian's believe the talk is about them.

For the purposes of this study we will describe the middle class solely in terms of household income. The middle class is defined in this section as those with disposable incomes higher than the bottom 30 per cent and lower than the richest 20 per cent. We want to test whether the middle class shrank over the 11-year period 1994-95 to 2005-06. It would perhaps have been preferable to test the hypothesis over a longer period but problems with comparability of data precluded this (Siminski et al. 2003). If the middle class did shrink, did those who left its ranks get pushed into the low-income group (the bottom 30 per cent) or graduate into the high-income group (the top 20 per cent)?

To test whether the middle class has been shrinking we employ a technique with four steps.

1. For the base year 1994-95 we first find the lower and upper boundaries for disposable incomes of those households that comprise the 'middle' 50 per cent, i.e. between the $30^{\text {th }}$ and the $80^{\text {th }}$ percentiles.

2. Next we calculate these dollar-value cut-off points as multiples of the median level of disposable income for the middle class so defined.

3. Now we take the median level of disposable income for 2005-06 and apply the 199495 multiples to the 2005-06 median to find the new cut-off points for the middle class.

4. Finally, we calculate the proportion of households that fall within these cut-off points in 2005-06. If it is less than 50 per cent of all households then the middle class has shrunk, if more than 50 per cent then it has grown.

More details of the method and data are given in the appendix.

The results of the analysis are shown in Figure 5. Note that in 1994-95 the lower boundary for the middle class stood at 0.635 of the median and the upper boundary stood at 1.771 of the median. 
Figure 5 The changing size of the middle class, 1994-95 to 2005-06

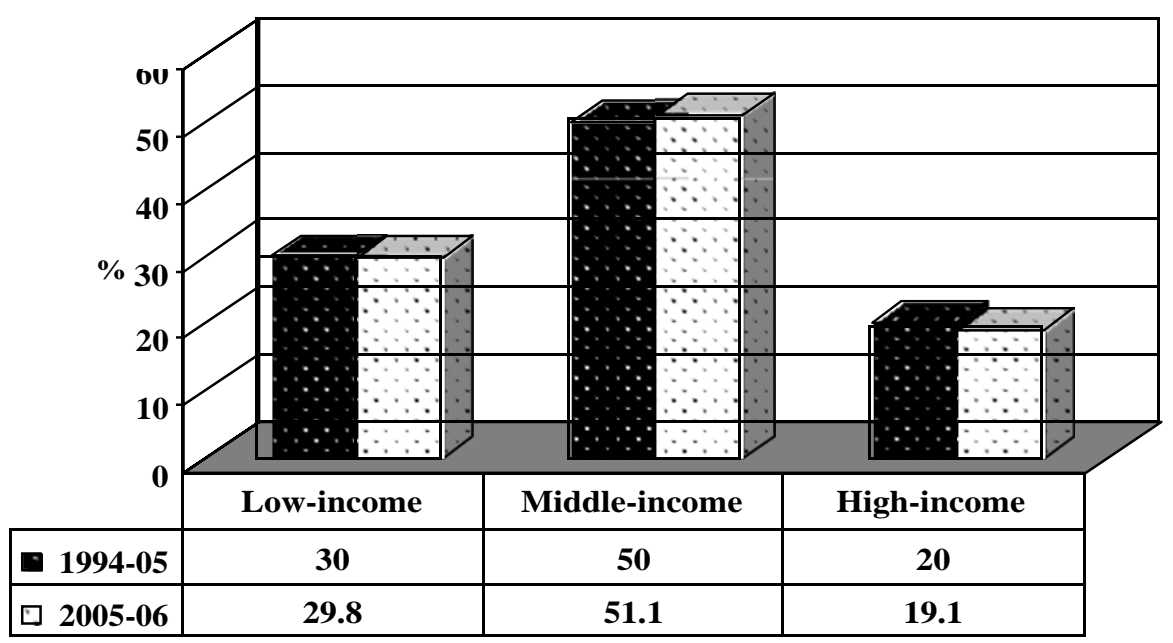

Source: Unpublished data from the ABS.

Over the 11 years to 2005-06 the middle class has in fact expanded, from 50 per cent to 51.1 per cent of households. The difference is small but it disproves the claim that the middle class is shrinking, at least when measured in this way. The growth in the middle class has been due mostly to the migration of households from the high-income category. When the same method is applied to equivalised disposable incomes the results show the middle class growing by the same amount, although the growth is fuelled mostly by migration from the low-income group instead of from the high-income group. ${ }^{7}$

Obviously, the incomes of all groups grew over the period in question. But perhaps they did not grow to the same extent. The middle class may have grown in numbers but its relative position may have declined. To test this we calculate the growth in mean disposable household incomes for the low, middle and high-income groups in constant prices. The results are shown in Table 2.

\footnotetext{
${ }^{7}$ Equivalised disposable household income accounts for differences in the composition of the household. See appendix for further discussion.

Permission to reprint this article in this journal was given by The Australia Institute and the Authors. This work originally appeared as Discussion Paper 98, October, 2007 on the Australia Institute Website at www.tai. org. au

(c) The Australia Institute 2008

This work is copyright. It may be reproduced and communicated to the public for the purposes of fair dealing as provided by the Copyright Act 1968. The author maintains their moral rights in this work. Requests and inquiries should be directed to The Australia Institute.
} 
Table 2 Mean disposable household income by income group in 2005-06 dollars, 1994-95 to 2005-06

\begin{tabular}{lllll}
\hline Household type & $1994-95$ & $2005-06$ & $\begin{array}{l}\text { Percentage } \\
\text { change in real } \\
\text { income }\end{array}$ & $\begin{array}{l}\text { Percentage change } \\
\text { in real equivalised } \\
\text { income }\end{array}$ \\
\hline Low-income & $\$ 13,869$ & $\$ 18,405$ & 33 & 32 \\
Middle-income & $\$ 41,764$ & $\$ 53,079$ & 27 & 32 \\
High-income & $\$ 91,610$ & $\$ 120,339$ & 31 & 37 \\
\hline All households & $\$ 43,380$ & $\$ 55,581$ & 28 & 34 \\
\hline
\end{tabular}

Source: Unpublished data from the ABS.

Overall, real disposable incomes over the 11 year period have increased by more than a quarter (28 per cent). The last column shows the percentage increase in mean equivalised disposable income for each group (the incomes themselves are not shown). Adjusting for household composition it is apparent that living standards have improved by a third (34 per cent).

It is apparent that both the low and the high-income groups have done better than the middleincome group. Although the average real income of the middle class rose 27 per cent over the 11 years to 2005-06, low-income households saw their incomes rise by 33 per cent and highincome households by 31 per cent. In terms of equivalised real incomes, the high-income group did substantially better than the low and middle-income groups -37 per cent for the high-income group versus 32 per cent for both of the others.

\section{Are 'working wives' saving the day?}

It has been suggested that the only reason household incomes have increased is because women in couple households have been working longer hours (Rose 2007). We know that more women work now than a decade ago and many are working longer hours. In fact, between 1994-95 and 2005-06 female average hours worked increased from 725 hours per year to 866 hours per year, an increase of 19 per cent (ABS 1996; 2007).

However, does this mean that 'working wives' are propping up the increases in household incomes? Are 'working wives' saving the day? To test this we compare the increase in mean disposable incomes of couple households over the period 1994-95 to 2005-06 with the increase that would have occurred if the females in the couple households ('wives') had not increased their hours of work from their levels in the earlier year. The data were commissioned for this report from the ABS. More detail of data and methods are given in the appendix.

Table 3 shows the mean disposable household income for all couple households for 1994-95 and 2005-06, adjusted for inflation. It also shows the hours of work by females in the two years. The data are shown by disposable income quintile. To test for the influence of 'working wives', we deducted from household disposable income the wage and salary component of 
the female partner, adjusted it downwards to exclude the effect of increases in working hours, then added the adjusted figure back in. ${ }^{8}$

Average disposable incomes of couple household increased from \$51,201 (measured in 200506 dollars) to $\$ 68,668$ over the 11 years to $2005-06$, a rise of 34 per cent in real terms. Couple households in the lowest income quintile experienced the largest increase (50 per cent) followed by those in the highest income quintile ( 36 per cent).

The last column in Table 3 shows that if there had been no increase in hours worked by women in couple households then the real disposable income of couple households would have increased by 28 per cent instead of 34 per cent. In other words, only 18 per cent of the growth of incomes in couple households over the 11 years to 2005-06 is accounted for by longer working hours by the female partner.

There are, however, some marked differences between the quintiles. Increased working hours by wives made very little difference to households in the lowest and highest quintiles (accounting for only eight and five per cent of the growth in household income, and a larger but still small contribution in the fourth quintile (16 per cent). In the second and third quintiles the contribution of 'working wives' was greater, accounting for 26 and 37 per cent of increased household income.

Table 3 Mean disposable household income for couple households in 2005-06 dollars, 1994-95 to 2005-06

\begin{tabular}{|c|c|c|c|c|c|c|}
\hline $\begin{array}{l}\text { Income } \\
\text { quintile }\end{array}$ & $\begin{array}{l}1994-95 \\
\text { mean } \\
\text { disposable } \\
\text { household } \\
\text { income }\end{array}$ & $\begin{array}{l}2005-06 \\
\text { mean } \\
\text { disposable } \\
\text { household } \\
\text { income }\end{array}$ & $\begin{array}{l}\text { Percent- } \\
\text { age } \\
\text { change } \\
\text { in real } \\
\text { income }\end{array}$ & $\begin{array}{l}1994-95 \\
\text { mean } \\
\text { weekly } \\
\text { hours of } \\
\text { work by } \\
\text { females }\end{array}$ & $\begin{array}{l}2005-06 \\
\text { mean } \\
\text { weekly } \\
\text { hours of } \\
\text { work by } \\
\text { females }\end{array}$ & $\begin{array}{l}\text { Percentage } \\
\text { change if } \\
\text { women had } \\
\text { worked the } \\
\text { same hours }\end{array}$ \\
\hline Lowest & $\$ 15,851$ & $\$ 23,776$ & 50 & 2.1 & 3.0 & 46 \\
\hline Second & $\$ 32,170$ & $\$ 43,328$ & 35 & 5.3 & 8.5 & 26 \\
\hline Third & $\$ 46,561$ & $\$ 61,317$ & 32 & 13.5 & 19.2 & 20 \\
\hline Fourth & $\$ 62,568$ & $\$ 80,713$ & 29 & 22.2 & 24.8 & 24 \\
\hline Highest & $\$ 98,962$ & $\$ 134,261$ & 36 & 26.4 & 27.6 & 34 \\
\hline $\begin{array}{l}\text { All house- } \\
\text { holds }\end{array}$ & $\$ 51,201$ & $\$ 68,668$ & 34 & 13.9 & 16.6 & 28 \\
\hline
\end{tabular}

Source: Unpublished data from the ABS

\footnotetext{
${ }^{8}$ Note that the income of females is not all earned. In the lowest quintile, it makes up only a small proportion of total income. The wage and salary component of female earnings are only available as gross figures, i.e. before tax, and this introduces an error into the calculations. The effect of the error is to exaggerate the effect of wives working longer, so to the extent that we conclude that increased hours from working hours is not significant, using the true figures would only reinforce this conclusion.

Permission to reprint this article in this journal was given by The Australia Institute and the Authors. This work originally appeared as Discussion Paper 98, October, 2007 on the Australia Institute Website at www.tai. org.au

(C) The Australia Institute 2008

This work is copyright. It may be reproduced and communicated to the public for the purposes of fair dealing as provided by the Copyright Act 1968. The author maintains their moral rights in this work. Requests and inquiries should be directed to The Australia Institute.
} 
Is the picture the same for families, that is, couple households with one of more children? The analysis has been repeated for this subset of couple households. The results are shown in Table 4. The picture is little changed. Between 1994-95 and 2005-06 the real disposable income of couples with children increased by 40 per cent, from $\$ 56,207$ to $\$ 78,419$. The incomes of the lowest quintile increased 54 per cent, substantially more than all others.

If there had been no increase in hours worked by women in couple households then the real disposable income of couple households with children would have increased by 32 per cent instead of 40 per cent. In other words, 18 per cent of the growth of incomes in these households over the 11 years to 2005-06 is accounted for by the longer working hours of the female partner. ${ }^{9}$

Across the quintiles the picture is very similar to that of all couple households, although in the lowest quintile the 'working wives' effect accounts for 17 per cent of the growth of income instead of the eight per cent that applies to all couple households.

Table 4 Mean disposable household income for couple households with children in 200506 dollars, 1994-95 to 2005-06

\begin{tabular}{|c|c|c|c|c|c|c|}
\hline $\begin{array}{l}\text { Income } \\
\text { quintile }\end{array}$ & $\begin{array}{l}1994-95 \\
\text { mean } \\
\text { disposable } \\
\text { household } \\
\text { income }\end{array}$ & $\begin{array}{l}2005-06 \\
\text { mean } \\
\text { disposable } \\
\text { household } \\
\text { income }\end{array}$ & $\begin{array}{l}\text { Percent- } \\
\text { age } \\
\text { change } \\
\text { in real } \\
\text { income }\end{array}$ & $\begin{array}{l}1994-95 \\
\text { mean } \\
\text { weekly } \\
\text { hours of } \\
\text { work by } \\
\text { females }\end{array}$ & $\begin{array}{l}2005-06 \\
\text { mean } \\
\text { weekly } \\
\text { hours of } \\
\text { work by } \\
\text { females }\end{array}$ & $\begin{array}{l}\text { Percentage } \\
\text { change if } \\
\text { women had } \\
\text { worked the } \\
\text { same hours }\end{array}$ \\
\hline Lowest & $\$ 21,951$ & $\$ 33,787$ & 54 & 3.3 & 5.7 & 45 \\
\hline Second & $\$ 39,366$ & $\$ 54,747$ & 39 & 7.1 & 12.7 & 26 \\
\hline Third & $\$ 50,732$ & $\$ 69,815$ & 38 & 13.4 & 19.8 & 25 \\
\hline Fourth & $\$ 65,384$ & $\$ 87,960$ & 35 & 21.6 & 24.0 & 30 \\
\hline Highest & $\$ 104,019$ & $\$ 145,836$ & 40 & 25.2 & 25.2 & 40 \\
\hline $\begin{array}{l}\text { All house- } \\
\text { holds }\end{array}$ & $\$ 56,207$ & $\$ 78,419$ & 40 & 14.1 & 17.5 & 32 \\
\hline
\end{tabular}

Source: Unpublished data from the ABS

\section{Explaining the difference between perception and reality}

In March 2007, the Prime Minister told Australian families that they 'have never been better off' (Howard 2007). Data on the growth in real incomes in Australia since the early 1990s shows that, in material terms, this statement is unquestionably true. Yet even politicians who have presided over a period of sustained economic growth understand that there are dangers

\footnotetext{
${ }^{9}$ Figures may look a little out due to rounding.

Permission to reprint this article in this journal was given by The Australia Institute and the Authors. This work originally appeared as Discussion Paper 98, October, 2007 on the Australia Institute Website at www.tai. org.au

(C) The Australia Institute 2008

This work is copyright. It may be reproduced and communicated to the public for the purposes of fair dealing as provided by the Copyright Act 1968. The author maintains their moral rights in this work. Requests and inquiries should be directed to The Australia Institute.
} 
in telling people that they are doing well, with its implication that they should be appreciative and not complain.

The frequent use by politicians, commentators and the media of the rhetoric of struggle suggests that Australians like to see themselves as doing it tough and are prone to confuse imagined for real deprivation. The Leader of the Opposition responded to Mr Howard's claim saying that he is 'out of touch' (Rudd 2007) and reiterated Labor's argument about struggling families. In fact, both claims appear to be true: Australians have indeed never been better off, but to make such a claim is indeed out of touch with the feelings of Australians.

The data presented in this paper show that, if families are thought of as comprising a couple with dependent children, few typical Australian families can be said to be struggling. In 200506 the typical Australian family had a household income of $\$ 69,073$ after tax. And if we look at all middle-income households, their disposable income has increased by 27 per cent in real terms over the last 11 years.

Across all household types, if we focus on those headed by a prime age adult (excluding those studying, recent entrants to the workforce, the retired or those approaching retirement), the median disposable income is $\$ 58,282$.

Despite the avalanche of headlines and commentary claiming that swathes of home-owners, including middle-class ones, are suffering from mortgage stress, in fact only 37 per cent of middle-class households have mortgages and only eight per cent have mortgages of more than $\$ 200,000$.

These figures counter the widespread view that the middle class in Australia is under pressure from all sides. It should not be a surprise, therefore, to find that the middle class - defined as households occupying the $30^{\text {th }}$ to $80^{\text {th }}$ percentiles of the income distribution - has not shrunk in recent times but has in fact grown slightly. It is true, however, that the real incomes of this group have not grown as quickly as those of the bottom 30 per cent and the top 20 per cent.

In response to the claim that it is only because 'working wives' are working longer hours that middle-class households are keeping their heads above water, the analysis of this paper shows that increased working hours by females in couple households accounts for only 18 per cent of the increase in household income over the 11 years to 2005-06, although the figure is somewhat higher for households in the second and third quintiles.

How can we explain the disconnect between the healthy financial position of the Australian middle class and the widespread perception of middle-class hardship? Three explanations suggest themselves. The first, and perhaps most obvious, is the effect of the rhetoric of struggle. While the truth is that only a small section of the population is actually struggling, when phrases like 'Aussie battler', 'doing it tough' and 'making ends meet' are regularly beamed into lounge rooms, Australians may believe those phrases describe their own situation irrespective of their real financial position.

Second, middle-class Australians imagine they are in hardship because they focus not on what they have but on the gap between what they have and what they want. There is considerable evidence for this (Hamilton and Denniss 2005). Rising aspirations are not necessarily harmful, but when they create a sense of material deprivation in a time of plenty they not only prevent people from appreciating their good fortune but induce government to provide 
welfare to households that are not in need, often at the expense of those who are. The expansion of 'middle-class welfare' in recent years - including the private health insurance rebate, the baby bonus, non-means tested family payments and extremely generous superannuation tax concessions - testify to the political power of middle-class perceptions of entitlement.

Third, middle-class Australians may be displacing anxieties about non-economic issues onto their financial circumstances. In addition, they may feel that the financial rewards of prosperity are inadequate in the face of the costs, such as overwork and family pressures. Studies conducted in the 1990s showed that when they reflect on the experience of economic reform many people display anger and disquiet (Pusey 2003, p. 174). Similar concerns have been discussed in Hamilton and Denniss (2005), including a widespread perception that Australia is in moral decline. Most people seem to believe that Australian society is too focussed on money and material things. It could be that anxiety about moral and social decline, pressure to succeed and fears about world affairs are displaced onto financial concerns. In other words, when middle-class Australians believe they are struggling, it may be that they are struggling with things other than their finances.

\section{References}

ABS 1996, Income Distribution, Australia, 1994-95, Cat. No. 6523.0, ABS, Canberra.

ABS 2007, Household Income and Income Distribution, Australia, 2005-06, Cat. No. 6523.0, ABS, Canberra.

Australian 2000, 'Death of the Nation's Great Middle-Class Dream', Australian, Weekend Edition, 17-18 June, Sydney.

Borland, J. 1999, 'Earnings Inequality in Australia: Changes, Causes and Consequences', Economic Record, Vol. 95, No. 229, pp. 177-202. https://doi.org/10.1111/j.1475-4932.1999.tb02448.x

Costello, P. 2007, 'Interview with Neil Mitchell', 3AW, 26 July.

Fujitsu 2007, 'Fujitsu consulting launches Mortgage 'Stress-O-Meter', media release, Fujitsu Consulting, 8 August, Sydney. (available at: <http://www.fujitsu.com/au/news/pr/archives/2007/20070809-01.html>).

Gregory, B. 1993, 'Aspects of Australian and US Living Standards: The Disappointing Decades 1970-1990', Economic Record, Vol. 69 No. 204. https://doi.org/10.1111/j.1475-4932.1993.tb01799.x

Gregory, B. 1996, 'Disappearing Middle or Vanishing Bottom? - A reply', Economic Record, Vol. 72, No. 218. Greenwell, H., Lloyd, R. and Harding, A. 2001, An Introduction to Poverty Measurement Issues, Discussion Paper, No. 55, National Centre for Social and Economic Modelling, University of Canberra, December.

Hamilton, C. 2003, 'Real and Imagined Hardship in Australia', Journal of Australian Political Economy, No. 52 , December.

Hamilton, C. and Denniss, R. 2005, Affluenza: When too much is never enough, Allen \& Unwin, Sydney.

Harding, A. 1997, The Suffering Middle: Trends in income inequality in Australia 1982 to 1993-94, Discussion paper, No. 21, National Centre for Social and Economic Modelling, University of Canberra, June, Canberra. https://doi.org/10.1111/1467-8462.304034

Harding, A., Ngu Vu, Q. and Payne, A. 2007, A Rising Tide? Income inequality, the social safety net and the labour market in Australia, National Centre for Social and Economic Modelling, July, Canberra.

Heady, B. Marks, G. and Wooden, M. 2005, 'The dynamics of income poverty in Australia: Evidence from the first three waves of the HILDA Survey', Australian Journal of Social Issues, Vol. 40, No. 4, Summer.

Heady, B. Warren, D. and Harding, G. 2006, Families, Incomes and Jobs: A statistical report of the HILDA survey, Melbourne Institute of Applied Economic and Social Research, University of Melbourne, Commonwealth of Australia, Melbourne.

Headey, B. 2007, 'HILDA's Household Financial Accounts: Their value for developing improved assessment of economic well-being \& poverty', Conference Paper, Melbourne Institute of Applied Economic and Social Research, University of Melbourne, July, Melbourne.

Howard, J. 2007, House of Representatives Official Hansard, Commonwealth of Australia, 26 March, p. 25.

Ife, H. 2007, 'Mortgage stress on the rise', Herald Sun, 17 August, Melbourne.

Leigh, A. 2006, 'Political economy of tax reform in Australia', Public Policy, Vol. 1, No. 1, pp. 52-60.

Magill, P. 2004, 'Changes put squeeze on the middle class', West Australian, 11 February, Perth.

Megalogenis, G. 2005, 'Hollowing out the backbone - Economy and Society', Australian, 4 June, Sydney.

Melbourne Institute of Applied Economic and Social Research (MIAESR) 2006, Household, Income and Labour Dynamics in Australia (HILDA) Survey Annual Report 2006, University of Melbourne, Melbourne.

Permission to reprint this article in this journal was given by The Australia Institute and the Authors. This work originally appeared as

Discussion Paper 98, October, 2007 on the Australia Institute Website at www.tai. org.au

(c) The Australia Institute 2008

This work is copyright. It may be reproduced and communicated to the public for the purposes of fair dealing as provided by the Copyright

Act 1968. The author maintains their moral rights in this work. Requests and inquiries should be directed to The Australia Institute. 
Pusey, M. 2003, The Experience of Middle Australia: The Dark Side of Economic Reform, Cambridge University Press, Cambridge https://doi.org/10.1017/CBO9780511481628

Rintoul, S. 2000, 'The new battlers - Advance Australia where', Australian, 17 June, Sydney.

Rose, S. 2007, Social Stratification in the United States, revised and updated, The New Press, New York.

Rudd, K. 2007, House of Representatives Official Hansard, Commonwealth of Australia, 27 March, p. 20.

P. Saunders, C. Thomson and C. Evans, 2000, Social Change and Social Policy: results from a national survey of public opinion, Discussion Paper No. 106, Social Policy Research Centre, University of New South Wales, Sydney.

Saunders, P. 2005, The Poverty Wars: Reconnecting research with reality, UNSW Press, Sydney.

Senate Community Affairs Reference Committee (SCARC) 2004, A Hand Up Not A Hand Out: Renewing the fight against poverty (Report on poverty and financial hardship), Commonwealth of Australia, March, Canberra.

Siminksi, P., Saunders, P., Waseem, S. and Bradbury, B. 2003, Assessing the quality and inter-temporal comparability of ABS household income distribution survey data, Social Policy Research Centre, Discussion paper No. 123, April.

Swan, W. 2007, 'Interview: Wayne Swan', Sunday Program, Channel Nine, 15 July, Sydney.

Tibbitts, A. 2007, 'Gambling on good health to make ends meet', Sydney Morning Herald, 7 August, Sydney.

Vallejo, J. 2007, 'Living on the Edge - Faces of the mortgage squeeze on the city fringes - Special Report', Daily Telegraph, 18 August, Sydney.

Vinson, T. 2007, Dropping off the edge: the distribution of disadvantage in Australia, A report of Jesuit Social Services and Catholic Social Services Australia, Melbourne.

Wooden, M. and Watson, N. 2007, 'The HILDA Survey and its Contribution to Economic and Social Research (So Far)', The Economic Record, Vol. 83, No. 261, pp. 208-231. https://doi.org/10.1111/j.1475-4932.2007.00395.x 


\section{Appendix on data and method Section 2: The income of the typical family}

When we think of the 'typical' Australian family we generally think of couples with dependent children where one or more of the parents works. The prime-age bracket is generally defined as people aged between 25 and 54 years (Borland 1999; Heady et al. 2006). In this paper when we consider the income of the typical Australian family, we consider households headed by someone in their prime working age and with dependent children and or dependent students.

\section{Data}

The data used in this part of the paper comes from Wave 5 release 5.1 of the Household, Income and Labour Dynamics in Australia (HILDA) Survey. HILDA was chosen as an appropriate data source because of its large sample and capacity to divide households between various types. Wave 5, for the year 2005, has a sample of 7,125 households.

The HILDA Survey incorporates sample weights to ensure, as far as possible, that the characteristics of the sample - such as age, sex and labour force status - mirror known totals for the population of households in Australia. The analyses in this paper use weighted data (Wooden and Watson 2007; MIAESR 2006).

\section{Income unit}

The income unit or level of income used is normally either personal income or household income. When determining the income of the typical Australian family it makes little sense to look at personal income given that most families share income and resources under the one roof. In the HILDA Survey the household is defined as a group of people who usually reside and eat together (Wooden and Watson, 2007).

In couple households the reference person is treated as the partner who is listed first in the household data file. It makes little difference if it is the male or female partner. In single parent households the reference person is the parent and in lone person households the reference person is that person.

For the purposes of this paper children are defined as natural, adopted, step or foster children who are under 15 years or who are dependent students. Dependent students are considered to be persons aged between 15 and 24 years, not employed full-time, are studying full-time, are living with at least one parent, and are without a partner or child of their own.

\section{Income measure}

The main income measures used to indicate a person's standard of living are private income, gross income, disposable income and final or social income (Greenwell et al. 2001). In this paper we look at two types of household income - gross and disposable. Gross household income is the combined income of all household members from all sources-labour income, asset income, private transfers and public transfers such as government benefits and pensions. Disposable income is much the same except that it is income after tax (Headey et al. 2006). This distinction is important, especially in Australia, where taxes and transfers have been shown to have a significant effect on income distribution. Using disposable income makes 
sense because it shows the amount of money families actually have to spend after they have paid their tax.

Both gross and disposable income are often referred to as 'before-housing income' because they do not deduct housing costs. While there are arguments for and against using afterhousing income (see Harding 1997), in this paper we use before-housing income because of the difficulties associated with deducting housing costs. This is in line with similar analyses (Headey et al. 2005; Headey et al. 2006).

\section{Measuring the typical family income}

Using data from the HILDA Survey we calculated the gross and disposable median and average (mean) incomes in 2005 for a range of household types. Gross household income was calculated by using the derived variable 'household financial year gross income', which has 7,125 observations. This variable was then recoded to exclude zeros and missing values. For the purpose of defining the 'reference person' (see above) we also excluded 'multi-family', 'group' and 'other' households. This left 6,882 or 96 per cent of the original sample. For completeness we also calculated gross household income with negative values included, which produced a negligible effect on gross household income. This approach was repeated for disposable household income using the variable 'household financial year disposable income', which has 7,125 observations and a similar of number of missing values.

Comparison of these results with equivalent data from the ABS suggests that the results are representative of household income in Australia (ABS 2007). However, the data produced from the HILDA Survey are slightly higher than those from the ABS. This can be explained by two factors. First, it is possible that the HILDA Survey over-samples higher occupation groups because the questions on occupation are not identical to those of the ABS (Headey et al. 2006). Second, although the household incomes from HILDA are higher than those from the ABS, they are closer to declared income from the Australian Tax Office (ATO). ${ }^{10}$ The ABS data thus suggest that people earn less than they declare on their tax forms, which the HILDA Survey considers unlikely. ${ }^{11}$

To calculate gross and disposable household income by different household type households were categorised according to a number of variables. Households were selected as prime-age where the reference person is aged between 25 and 54 years. This produced 3,939 prime-age households. Prime-age couple households were selected where the reference person in the couple is aged between 25 and 54 years. This produced 2,559 prime-age couple households. This process was repeated for prime-age couple household with dependent children, which left 1,709 households in this category.

As is evident, this analysis does not exclude households based on employment status. Some analyses of income exclude people who are unemployed and only consider full-time earnings. However, this has the effect of inflating the 'typical' income. First, the little income that unemployed people receive (largely from government) should be factored into calculations of income if the typical income is to be representative of the whole population. Second, because Australia has a high rate of part-time employment, any method that excludes earnings from part-time work by only including full-time earnings leaves out a large swathe of the

\footnotetext{
${ }^{10}$ Personal communication with Simon Freidin from HILDA, 14 August 2007.

${ }^{11}$ Ibid.

Permission to reprint this article in this journal was given by The Australia Institute and the Authors. This work originally appeared as Discussion Paper 98, October, 2007 on the Australia Institute Website at www.tai. org.au 
population and therefore cannot claim to represent 'typical' income (Leigh 2006). By including all income earnings, irrespective of employment status, we provide a truer picture of the typical family income in Australia.

\section{Section 3: Mortgages and the middle class}

Using data from the HILDA Survey, described above, we first defined the middle class as those households whose gross disposable household income falls in the $30^{\text {th }}$ and $80^{\text {th }}$ percentile band. This was done using the derived variable 'household financial year disposable income', which was recoded to exclude zeros and missing values. 'Multi-family', 'group' and 'other' households were also excluded so the analysis was consistent with that in section 2 . This left 3,392 households as 'middle class' with an income between $\$ 29,960\left(30^{\text {th }}\right.$ percentile) and $\$ 81,489\left(80^{\text {th }}\right.$ percentile $)$.

To calculate the percentage of middle-class households that have a mortgage we recoded the variables 'approximate outstanding on home loan' and 'second mortgages or home equity loans are secured on property' as 'total mortgage'. This left 1,277 middle-class households with a mortgage, or 36.6 per cent when weighted using the household population weight. 'Mortgage' is defined here as first and other home loan secured against the property (household home) excluding loans from friends, other organisations or secured against another property. In other words, this details the amount left outstanding from multiple mortgages.

\section{Section 4: The size of the middle class}

\section{Data}

The data used in this part of the paper come from the 1994-95 and 2005-06 ABS Surveys of Income and Housing (SIH). The SIH was chosen as an appropriate data source to answer this question because it, unlike the HILDA Survey which only goes back to 2001, has been conducted almost continuously between 1994-95 and 2005-06 and thus allows comparisons in income distribution to be made over time.

Some concerns have been raised about the quality of ABS income data and its comparability over time. Siminski et al. (2003) have argued that the main problems relate to the underreporting of income, major differences in weighting methodologies between surveys as well as methodological, definitional and scope differences. These problems are more acute when making comparisons between current ABS income data and income data from the 1980s and 1970s. To minimise these potential problems we chose to make comparisons only as far back as 1994-95 using the SIH, although tracking the size of the middle class over a longer period would have been preferable.

The 2005-06 final SIH sample consisted of 9,961 households, comprising 19,212 persons aged 15 years and over (ABS 2007). The 1994-95 final SIH sample consisted of 6,819 households, comprising 13,827 persons aged 15 years and over (ABS 1996). In addition, the data from the $\mathrm{SIH}$ are weighted to ensure, as far as possible, that the characteristics of the sample match known totals for the population of households in Australia. 


\section{Income unit}

As discussed above, when considering family income it makes sense to use household income rather than personal income. The ABS defines a household as 'a person living alone or a group of related or unrelated people who usually live in the same private dwelling' (ABS 2007). As with the HILDA Survey, households are classified according to the reference person. The ABS determines the reference person, in a similar manner to the HILDA Survey, as the person in the household 15 years and over with most responsibility in the household. ${ }^{12}$ Dependent children in the household are defined as 'all persons aged under 15 years; and persons aged 15-24 years who are full-time students, have a parent in the household and do not have a partner or child of their own in the household' (ABS 2007).

\section{Equivalence scales}

When assessing changes in economic well-being it is useful to adjust household income for differences in the composition of the household. Because the costs of living do not rise in direct proportion to the number of people living in a household, an equivalence scale is used.

A number of different equivalence scales can be used (Harding 1997; Greenwell et al. 2001). The ABS uses a 'modified OECD' scale. The equivalence factor is derived by allocating points to each person in a household. The first adult is given a weight of 1, each additional person 15 years and over is given a weight of 0.5 , and each child under the age of 15 is allocated 0.3 points. Equivalised household income is calculated by dividing total household income by the sum of the weights given to each person in the household. In a lone person household the equivalised income is the same as the non-equivalised income (ABS 2007).

\section{Measuring changes in the size of the middle class}

Any attempt to measure changes in income distribution over time must confront a number of obstacles. The data sources must be consistent with the definitions of the income unit and the income measure used. Comparisons must also consider whether to adopt relative or absolute measures of changes in income distribution. Some of these obstacles are not easily addressed and there is much contention in the literature about which methods are best (see for example, Harding et al. 2007).

We have attempted to address these issues by taking an approach that is simple, transparent and consistent with previous analyses of income distribution in Australia. Using data from the 1994-95 and 2005-06, the method (adapted from that used by Gregory (1993)) can be summarised as follows.

- Rank gross disposable household income in percentiles for the baseline period 1994-95.

\footnotetext{
${ }^{12}$ The reference person for each household is chosen by applying, to all household members aged 15 years and over, the selection criteria below, in the order listed, until a single appropriate reference person is identified:

- $\quad$ one of the partners in a registered or de facto marriage, with dependent children

- $\quad$ one of the partners in a registered or de facto marriage, without dependent children

- a lone parent with dependent children

- the person with the highest income

- the eldest person (ABS 2007).

Permission to reprint this article in this journal was given by The Australia Institute and the Authors. This work originally appeared as Discussion Paper 98, October, 2007 on the Australia Institute Website at www.tai. org.au 
- Divide the income distribution into three groups.

- ' 'low income' - the lowest 0-30 per cent of gross disposable household income.

- 'middle income' - the middle 31-80 per cent of gross disposable household income.

- 'high income' - the highest 81-100 per cent of gross disposable household income.

- Determine the cut-off points of these categories as multiples of the median gross disposable household income. (In 1994-95 the cut-off point for 'low income' $\left(30^{\text {th }}\right.$ percentile) was 0.635 of the median income. The cut-off point for 'middle income' $\left(80^{\text {th }}\right.$ percentile) was 1.771 times the median income.)

- Rank gross disposable household income in percentiles for the period 2005-06.

- Determine the cut-off points of the income groups for 2005-06 by applying the same multiples calculated for $1994-95$ (0.635 and 1.771) to the median income for 2005-06.

- Count the percentage of households that fall within each income group in 2005-06.

- This process was then repeated using equivalised gross disposable household income.

To ensure the reliability of the estimates derived from this method, Relative Standard Errors (RSEs) were calculated. The ABS recommends that any estimates with RSEs over 25 per cent should be considered with caution because the sampling variability is high. In this analysis RSEs did not exceed 25 per cent.

There are two points to note about this method. First, by defining the middle class as an income band within the income distribution, this approach avoids many of the problems associated with developing a definition based on other characteristics such as occupation type.

Second, by measuring changes in the size of the middle class using multiples of median income, this approach uses a 'relative' method as opposed to an 'absolute' method. This is consistent with most analyses of income distribution and makes sense given that changes in the percentage shares of income is inherently a relative concept (Gregory 1993, 1996).

\section{Section 5: The contribution of 'working wives'}

In this section the aim is to determine whether the rise in household income is partly a result of 'wives' working longer hours. In other words, we assess the extent to which increases in household income over the relevant period can be attributed to more hours worked by females in couple households (Rose 2007). 


\section{Data}

The data used in this part of the paper come from the 1994-95 and 2005-06 ABS SIH, described above.

\section{Income unit}

Two income units were used in this section - couple households and couple households with dependent children. Couple households include 'couple only households', 'couple family with dependent children' and 'other one family households'. Couple households with children are simply 'couple family with dependent children'. Dependent children are as defined by the ABS above. Each household type is defined by the ABS as follows:

- Couple only - two persons in a registered or de facto marriage, who usually live in the same household.

- Couple family with dependent children - a household consisting of a couple with at least one dependent child. The household may also include non-dependent children, other relatives and unrelated individuals.

- Other one family households - a household comprising:

- one couple with their non-dependent children only

- one couple, with or without non-dependent children, plus other relatives

- one couple, with or without non-dependent children or other relatives, plus unrelated individuals (ABS 2007).

\section{Income measure}

As described above, the income measure used is gross disposable income. This was chosen to keep the analysis consistent and because in making decisions to go out and work couples generally consider the net effect on household income, that is, after tax. Annual figures were calculated by multiplying weekly income by 52.14, in accordance with ABS guidelines.

\section{Measuring the change in household income when 'wives' working hours are held constant}

Using data from 1994-95 and 2005-06, the method used can be summarised as follows.

- Calculate the mean weekly household disposable income for couple households by quintile for 1994-95 and 2005-06.

- Convert 1994-95 income to 2005-06 prices.

- Calculate the mean weekly wages and salaries of the female in the couple household by quintile for 1994-95 and 2005-06. 
- Calculate the mean weekly hours worked by the female by quintile for 1994-95 and $2005-06{ }^{13}$

For each quintile we calculated the notional household disposable income in 2005-06 if the female had worked the same hours as in 1994-95 using the following formula.

$\mathrm{NHDI}=(\mathrm{A}-\mathrm{B})+\mathrm{B} * \mathrm{C} / \mathrm{D}$

Where:

$$
\begin{aligned}
& \text { NHDI = notional household disposable income in 2005-06 } \\
& A=\text { mean weekly household disposable income in 2005-06 } \\
& \text { B = mean weekly wages and salaries of the female in 2005-06 } \\
& \text { C }=\text { mean weekly hours of work by females in 1994-95 } \\
& \text { D = mean weekly hours of work by females in 2005-06. }
\end{aligned}
$$

The actual household disposable income and the notional household disposable income in 2005-06 are then compared to the actual household disposable income in 1994-95.

This method was repeated for all couple households with dependent children.

Note that ' $\mathrm{B}$ ' is gross wages and salaries, i.e. before tax. Use of the gross figure was unavoidable as the ABS can only provide a breakdown of personal income of the female into wages and salaries and non-labour income in gross terms. The effect of the use of gross wages and salaries of females is to overstate the contribution of increased hours by females to the growth in household income.

As above, RSEs were calculated but did not exceed 25 per cent, indicating that the estimates derived from this method are reliable.

\footnotetext{
${ }^{13}$ Hours worked in this analysis is based on employee hours only and does not include hours worked by selfemployed females.

Permission to reprint this article in this journal was given by The Australia Institute and the Authors. This work originally appeared as Discussion Paper 98, October, 2007 on the Australia Institute Website at www.tai. org.au 